\title{
Studies on Soil Acrasieae
}

\section{Distribution of species of Dictyostelium in soils of Great Britain and the effect of bacteria on their development}

\author{
By B. N. SINGH
}

Department of Soil Microbiology, Rothamsted Experimental Station, Harpenden, Herts

SUMMARY : A method of isolating species of Dictyosteliaceae from soil and other substrates is described.

Of ninety-three different strains of bacteria tested as food for Dictyostelium giganteum and $D$. mucoroides, some were readily or slowly but completely eaten, others were partly eaten and the rest were inedible. No correlation between the edibility of the bacteria and the formation of normal fruiting bodies could be found. More Gramnegative than Gram-positive strains were edible, and non-pigmented bacteria proved more suitable than pigmented bacteria for the normal development of Dictyostelium spp.

Values of $\mathrm{pH}$ between $4 \cdot 1$ and 8.9 had no effect on the abundance or on the types of fruiting bodies produced in either $D$. giganteum or $D$. mucoroides when suitable strains of bacteria were supplied as food to the myxamoebae on non-nutrient agar.

The maximum dimensions and the form of sorocarps and occasionally the colour of the sori were influenced by the type of bacteria used as food supplies. The influence of the bacterial food supply on the classification of Acrasieae is discussed and one new species $(D$. giganteum $)$ is described.

Species of Dictyostelium are frequently present in arable soils in Great Britain. The common occurrence of Dictyostelium spp. in soils, which have been unmanured or treated with artificial fertilizers only for 100 years or more, disproves the belief that Dictyostelium spp. are dung organisms.

The amoeboid protists included in the Acrasieae apparently occupy a position near the divergence of the plant and animal kingdoms. The vegetative stage consists of myxamoebae which feed and reproduce like true amoebae, but under suitable conditions of culture produce fruiting structures of definite and consistent form. The Acrasieae have been considered by botanists as plants and by protozoologists as Protozoa.

The genera Dictyostelium and Polysphondylium were created by Brefeld in 1869 and 1884 respectively and species belonging to these genera have since been described by various workers (cf. review by Raper, 1940 $a$ ). It was not, however, until recently that Raper $(1937,1939,1940 a, b)$ threw considerable light on the cultural characters and food requirements of the myxamoebae of Dictyostelium discoideum; his studies have led to the development of a better way of cultivating, classifying, and studying organisms included in Acrasieae.

The occurrence of Dictyostelium spp. in Polish and American soils has been recorded by Krzemieniewski (1927) and by Raper \& Thom (1932). Polyspondylium spp. have been rarely seen in soils. In 1944 Raper stated in a personal communication that he had isolated Dictyostelium spp. from soils from Australia, India, Mexico, Brazil, Cuba and numerous stations throughout the United States. 
The study of differential feeding by soil protozoa (especially amoebae) carried out by the writer on a large number of 'miscellaneous' strains of bacteria (Singh, 1941, 1942, 1945, 1946 $a, b$ ) led to improvements in isolating and studying members of the Acrasieae. A method of counting holozoic protozoa (Singh, 1946a,b) has been developed which is based on the differential feeding of amoebae. In this method a pure culture of a suitable bacterial species or a mixture of a few species is given as food for the development of protozoa on a substrate of non-nutrient agar or silica jelly. The use of this method revealed the common occurrence of Dictyostelium spp. in arable soils.

\section{Method of isolation and culture of Dictyostelium spp.}

The method of isolation has been described (Singh, 1946c). One or two loopfuls of a suitable bacterium growing usually on nutrient agar (2-7-day culture) is spread over the surface of non-nutrient agar ( $1.5 \%$ washed agar in $0.5 \%$ $\mathrm{NaCl} ; \mathrm{pH} 6 \cdot 5-6 \cdot 8)$ in the form of a disk or 'bacterial circle' of about an inch in diameter. In this way the growth of micro-organisms except those that feed on bacteria is checked. Several such circles are made in each Petri dish. These cultures are then inoculated at the centres either with very small crumbs of soil, diluted soil suspension, or with small portions of some other substrate and the plates then incubated at $21-23^{\circ}$ for $10-15$ days and examined at intervals.

The myxamoebae feed on the bacteria, reproduce actively and then form a pseudoplasmodium which gives rise to a fruiting body. All these stages can be seen in the crude cultures by examining the plates at frequent intervals. The crude cultures usually contain large numbers of true amoebae, both active and cystic, fruiting bodies of myxobacteria (Singh, 1947), fruiting bodies and myxamoebae of Dictyostelium spp. and other micro-organisms which feed on bacteria. The myxamoebae of the Dictyosteliaceae are indistinguishable from small true amoebae. In order to encourage the growth of the Dictyosteliaceae, strains of bacteria are selected which are readily eaten by the myxamoebae and lead to the production of normal fruiting bodies but which are not suitable as food for the active development of the amoebae. It is preferable to use Gram-negative strains of bacteria, because these do not encourage the development of lytic actinomycetes which are abundantly present in arable soils.

From the crude cultures species of Dictyosteliaceae are isolated in 'pure mixed' cultures as follows. A spore mass or sorus raised well above the surface of the agar and free from fungal growth is gently punctured by a fine sterilized needle and the spores transferred to freshly prepared 'bacterial circles' on nonnutrient agar plates. Within a few days large numbers of fruiting bodies are formed. By repeating this process a few times 'pure mixed' cultures of Dictyostelium spp. are obtained living on one species of bacteria. Sub-cultures are made every 1-2 months in order to maintain stock cultures.

Aerobacter strain 1912 (Singh, 1941) was extensively used in the beginning of the work to isolate species of Dictyostelium from various soils, and now this strain is mainly used to maintain stock cultures. 


\section{Influence of bacterial food on the growth of two species of Dictyostelium}

The role of bacteria in the nutrition of myxamoebae was not understood by the majority of the earlier workers (see Raper, 1937), although a few of them grew $D$. mucoroides in association with several species of bacteria on solid media containing nutrients. Raper (1937) and Raper \& Smith (1939) carried out detailed work to test the effects of more than thirty saprophytic and twentytwo strains of pathogenic bacteria (animal and plant pathogens) on the growth of $D$. discoideum. Hay infusion agar of constant composition was mostly used as a substrate. The bacteria to be tested were grown for 2-3 days on hay infusion agar and then spores of $\boldsymbol{D}$. discoideum were inoculated on to the same cultures. The comparative growth of $D$. discoideum in association with different bacteria was determined after 6-8 days by counting the number of large, medium, and small sorocarps. Raper (1937) found that, on the whole, better growth occurred with Gram-negative than with Gram-positive species. $D$. discoideum also grew well and consumed the colonies of nearly all the associated pathogenic bacteria grown on hay infusion agar. D. mucoroides, $D$. purpureum, and Polysphondylium violaceum grew well on several of the pathogenic bacteria tested (Raper \& Smith, 1939).

Many kinds of infusions and nutrients have been incorporated in agar to grow Acrasieae. In the long experience of the writer it has been found that agar containing nutrients is neither satisfactory for testing the growth of Protozoa on different bacteria nor for counting their numbers in soil or other substrates (Singh, 1941, 1942, 1945, 1946a,b). Nutrient media encourage the development of inedible organisms introduced with the inoculum, and may even encourage the growth of micro-organisms that produce substances having a detrimental effect on the growth of protozoa (Singh, 1945) and other protists. As myxamoebae, like true soil amoebae, feed selectively on bacteria, it is necessary that the cultural conditions should be properly controlled in order to test the effects of bacteria on the growth of the species of Dictyostelium. The writer considers it essential to use a non-nutrient substrate to isolate, to study the effects of bacterial food supplies, and to do quantitative work on those protists which can develop normally on bacteria as the exclusive source of food supply, if consistent and reliable results are to be obtained.

In order to study the effects of bacterial strains on Dictyostelium, 'bacterial circles' on non-nutrient agar were inoculated at the centres with spores of Dictyostelium spp. Cultures of bacteria of the same age (2-5 days) from nutrient agar slopes were always used to control the results. The plates were incubated at $21-\mathbf{2 3}^{\circ}$ for $7-10$ days. The main object has been to see what strains of bacteria are eaten by the myxamoebae and what effects these strains have on the production of fruiting bodies. The use of non-nutrient agar checked the multiplication of bacteria and no detectable change in the $\mathrm{pH}$ of the agar was observed where 'bacterial circles' were made. It can be assumed that the varying effects of different bacteria on the growth of myxamoebae and on the formation of fruiting bodies described in this paper are due to differences between the bacterial strains used. 
Table 1 shows the effects of ninety-three strains of bacteria on two species of Dictyostelium, D. mucoroides and $D$. giganteum a species proposed later as new. The bacteria used comprise eleven common, twenty-seven rare strains from soil, ten strains of plant pathogens $(4752,5945,1989,5944,5942,385,5943$, 387, 524I and 1997; cf. Singh, 1942, for the names of these strains), two strains of Rhizobium, and forty-three strains of 'miscellaneous' bacteria mostly isolated from soil. The bacteria tested fall into three groups. Some of the bacterial strains were completely eaten, either readily or slowly, others were only partly eaten and the rest were not eaten by the myxamoebae even when they were the only food supply. Several strains of bacteria were either completely or partly eaten by the myxamoebae but induced the production of

Table 1. Effects of bacterial food supply on the formation of fruiting bodies (FB) of two species of Dictyostelium

\begin{tabular}{|c|c|c|c|c|c|c|}
\hline \multirow[b]{2}{*}{ Species } & \multicolumn{2}{|c|}{ Completely eaten } & \multicolumn{2}{|c|}{ Partly eaten } & \multirow{2}{*}{$\begin{array}{l}\text { Not eaten } \\
\text { or slightly } \\
\text { eaten. } \\
\text { Few or no } \\
\text { FB, mostly } \\
\text { abnormal }\end{array}$} & \multirow{2}{*}{$\begin{array}{c}\text { Total } \\
\text { bacterial } \\
\text { strains } \\
\text { tested }\end{array}$} \\
\hline & $\begin{array}{c}\text { Normal } \\
\text { FB }\end{array}$ & $\begin{array}{c}\text { Abnormal } \\
\text { FB }\end{array}$ & $\begin{array}{c}\text { Normal } \\
\text { FB }\end{array}$ & $\begin{array}{c}\text { Abnormal } \\
\text { FB }\end{array}$ & & \\
\hline D. giganteum & 49 & 6 & 17 & 9 & 12 & 93 \\
\hline D. mucoroides & 55 & 5 & 16 & 9 & 8 & 93 \\
\hline
\end{tabular}

fruiting bodies which were abnormal in character. There seems to be no correlation between edibility and the production of normal fruiting bodies. The behaviour of the two species of Dictyostelium towards the different bacterial strains is similar except for a few strains. All the plant pathogenic bacteria were completely eaten and normal fruiting bodies were formed except in the case of strain 5241. This strain though eaten by the myxamoebae led to their producing abnormal fruiting bodies. Table 2 shows the edibility of Grampositive and Gram-negative strains of bacteria for two species of Dictyostelium. Gram-negative strains were somewhat more frequently eaten than the Grampositive, in accord with the findings of Raper (1937). In Table 3 the relation between pigmentation and edibility of bacterial strains is shown. The two species of Dictyostelium had a marked preference for non-pigmented strains. Red, violet, or green strains were least suitable for the growth of Dictyostelium spp. although unlike soil amoebae these organisms can feed on some such strains.

Influence of $\mathrm{pH}$ on the growth of $\mathrm{D}$. giganteum and $\mathrm{D}$. mucoroides

Raper (1939) deals with the effects of different nutrients incorporated in agar on the growth of $D$. discoideum with a few bacterial associates. He found that $\mathbf{1 . 2} \%$ peptone and a carbohydrate that could be fermented by the associated bacteria, provided a suitable substrate for the growth of the host bacteria and for the subsequent normal development of $D$. discoideum. In the absence of a fermentable carbohydrate the colonies of host bacteria became alkaline in reaction, owing to the accumulation of ammonia liberated from the 
peptone, and toxic to $D$. discoideum. The colonies of the same bacteria in the presence of a fermentable carbohydrate remained neutral or slightly acid because of the neutralization of the ammonia by acid products simultaneously formed from the carbohydrate, and these colonies were non-toxic to $D$. discoideum. Raper also claimed that the development of $D$. discoideum was governed by the $\mathrm{pH}$ of the bacterial colonies. The optimum reaction was pH 6.0-6.5 while excellent growth and normal fruiting bodies were formed in

Table 2. Edibility of Gram-positive and Gram-negative strains of bacteria for two species of Dictyostelium

\begin{tabular}{|c|c|c|c|c|c|c|}
\hline \multirow[b]{2}{*}{ Species } & \multicolumn{2}{|c|}{ Completely eaten } & \multicolumn{2}{|c|}{ Partly eaten } & \multirow{2}{*}{$\begin{array}{l}\text { Not eaten } \\
\text { or slightly } \\
\text { eaten. } \\
\text { Few or no } \\
\text { FB, mostly } \\
\text { abnormal }\end{array}$} & \multirow{2}{*}{$\begin{array}{c}\text { Total } \\
\text { bacterial } \\
\text { strains } \\
\text { tested }\end{array}$} \\
\hline & $\begin{array}{l}\text { Normal } \\
\text { FB }\end{array}$ & $\begin{array}{c}\text { Abnormal } \\
\text { FB }\end{array}$ & $\begin{array}{c}\text { Normal } \\
\text { FB }\end{array}$ & $\begin{array}{c}\text { Abnormal } \\
\text { FB }\end{array}$ & & \\
\hline D. giganteum & 20 & 1 & 11 & 6 & 8 & $\begin{array}{c}\text { Gram-positive } \\
\mathbf{4 6}\end{array}$ \\
\hline D. giganteum & 29 & 5 & 6 & 3 & 4 & $\begin{array}{c}\text { Gram-negative } \\
47\end{array}$ \\
\hline D. mucoroides & 24 & $\mathbf{1}$ & 11 & 5 & $\mathbf{5}$ & $\begin{array}{c}\text { Gram-positive } \\
46\end{array}$ \\
\hline D. mucoroides & 30 & 5 & 5 & 4 & 3 & $\begin{array}{c}\text { Gram-negative } \\
\mathbf{4 7}\end{array}$ \\
\hline
\end{tabular}

Table 3. Edibility of non-pigmented and pigmented strains of bacteria for two species of Dictyostelium

\begin{tabular}{|c|c|c|c|c|c|c|}
\hline \multirow[b]{2}{*}{ Species } & \multicolumn{2}{|c|}{ Completely eaten } & \multicolumn{2}{|c|}{ Partly eaten } & \multirow{2}{*}{$\begin{array}{l}\text { Not eaten } \\
\text { or slightly } \\
\text { eaten. } \\
\text { Few or no } \\
\text { FB, mostly } \\
\text { abnormal }\end{array}$} & \multirow{2}{*}{$\begin{array}{c}\text { Total } \\
\text { bacterial } \\
\text { strains } \\
\text { tested }\end{array}$} \\
\hline & $\begin{array}{l}\text { Normal } \\
\text { FB }\end{array}$ & $\begin{array}{c}\text { Abnormal } \\
\text { FB }\end{array}$ & $\begin{array}{l}\text { Normal } \\
\text { FB }\end{array}$ & $\begin{array}{c}\text { Abnormal } \\
\text { FB }\end{array}$ & & \\
\hline D. giganteum & 32 & 2 & 5 & 6 & 6 & $\begin{array}{c}\text { Non-pigmented } \\
\mathbf{5 1}\end{array}$ \\
\hline D. giganteum & 16 & 4 & 12 & 4 & 6 & $\begin{array}{c}\text { Pigmented } \\
42\end{array}$ \\
\hline D. mucoroides & $\mathbf{3 4}$ & 2 & 8 & 4 & $\mathbf{3}$ & $\underset{\mathbf{5 1}}{\text { Non-pigmented }}$ \\
\hline D. mucoroides & 20 & 3 & 10 & 5 & 4 & $\begin{array}{c}\text { Pigmented } \\
42\end{array}$ \\
\hline
\end{tabular}

bacterial colonies between $\mathrm{pH} 5 \cdot \mathbf{0}$ and $\mathbf{7 \cdot 0}$. Outside this range the growth of $\boldsymbol{D}$. discoideum progressively decreased and the development became abnormal. All growth ceased at $\mathrm{pH} 8 \cdot 5-8 \cdot 6$ and at $\mathrm{pH} 4 \cdot 0-4 \cdot 2$.

A simple experiment was devised to test the effects of $\mathrm{pH}$ on the growth of $D$. giganteum and $\boldsymbol{D}$. mucoroides when fed with suitable bacteria. 'Bacterial circles' of Bacterium coli, Pseudomonas fluorescens and Aerobacter strain 1912 were made on non-nutrient agar adjusted to $\mathrm{pH} 4 \cdot 1,4 \cdot 4,5 \cdot 4,5 \cdot 7,6 \cdot 0,6 \cdot 6,7 \cdot 0$, $7 \cdot 5,8 \cdot 2$ and 8.9. Spores of Dictyostelium spp. were inoculated in the centre of 
some of these cultures while others were left uninoculated as controls. The plates were incubated at 21-23 ${ }^{\circ}$. Within 3-5 days large numbers of normal fruiting bodies were produced and the bacterial cultures were completely eaten by the myxamoebae. At the end of 5 days bacteria from the control 'bacterial circles' were scraped off and a drop of indicator was added to the agar in this area and another drop to the agar away from the culture. No change could be detected in the $\mathrm{pH}$ of the agar in the area of the bacterial culture compared with agar away from it. Similarly no change in the $\mathrm{pH}$ of the agar could be found where slime moulds had grown with bacterial associates for 5 days. Thus it is reasonable to assume that $\mathrm{pH}$ values between $4 \cdot 1$ and $\mathbf{8 . 9}$ have no effect in determining the abundance or the types of fruiting bodies produced, either in $D$. giganteum or $D$. mucoroides. It is quite possible that the contrary results reported by Raper (1939) in the case of $D$. discoideum may be due not to the $\mathrm{pH}$ of the medium but rather to the metabolic products produced by the bacterial associates growing on the nutrients in the agar.

\section{Influence of bacterial food supplies on the classification of the Acrasieae}

The study of the effects of bacteria on the formation of fruiting bodies in Dictyosteliaceae and other groups of the Acrasieae is important in view of the confusion existing in the classification. Species of Dictyosteliaceae are generally classified by one or more of the following characters : (1) the colour of the spore mass or sorus, (2) the form of the fruiting bodies or sorocarps, and (3) the maximum dimensions of the sorocarps.

It has been found that some of the coloured strains of bacteria occasionally lead to the production of a few sori of red or yellowish colour. When the spores from these sori are cultured on the same or different suitable bacteria the sori produced are colourless. The fruiting bodies formed with some of the bacterial associates assume various abnormal shapes and forms. They may be either clumped together or one stalk may possess several sori; some of the fruiting bodies do not possess any stalks (Pl. 1, figs. 3, 5, 6, 7) and look like the fruiting structures of Guttulinopsis Olive and Guttulina Cienk. (Raper, 1940a). As the genera Guttulinopsis and Guttulina were described before the cultural characters of the amoeboid protists included in the Acrasieae were properly understood, it will be necessary to study these genera, if they are rediscovered, under controlled cultural conditions before they can be considered valid. The dimensions of the sorocarps also vary to such an extent that it is impossible to maintain species based on this character alone unless the organism has been grown under strictly controlled conditions and with a range of suitable bacterial foods. Dictyostelium giganteum (Text-fig. 1 and $\mathrm{Pl}$. 1, fig. 1) produces very long creeping stalks when grown on suitable bacterial associates, but on other bacterial associates the sorocarps are very short indeed and abnormal in character. Similar changes in the dimensions of the sorocarps have been found in D. mucoroides. Several species of the genus Dictyostelium: D. sphaerocephalum, D. brevicule, D. roseum, D. lacteum and D. aureum (Raper, 1940a) should only be considered valid if their diagnostic characters can be reproduced under controlled cultural conditions. So far only four easily identifiable 
species have been adequately studied (D. mucoroides Brefeld, 1869; D. purpureum Olive, 1901; D. discoideum Raper, 1935; and D. minutum Raper, 1941). Another species, $D$. giganteum, is now added to this list.

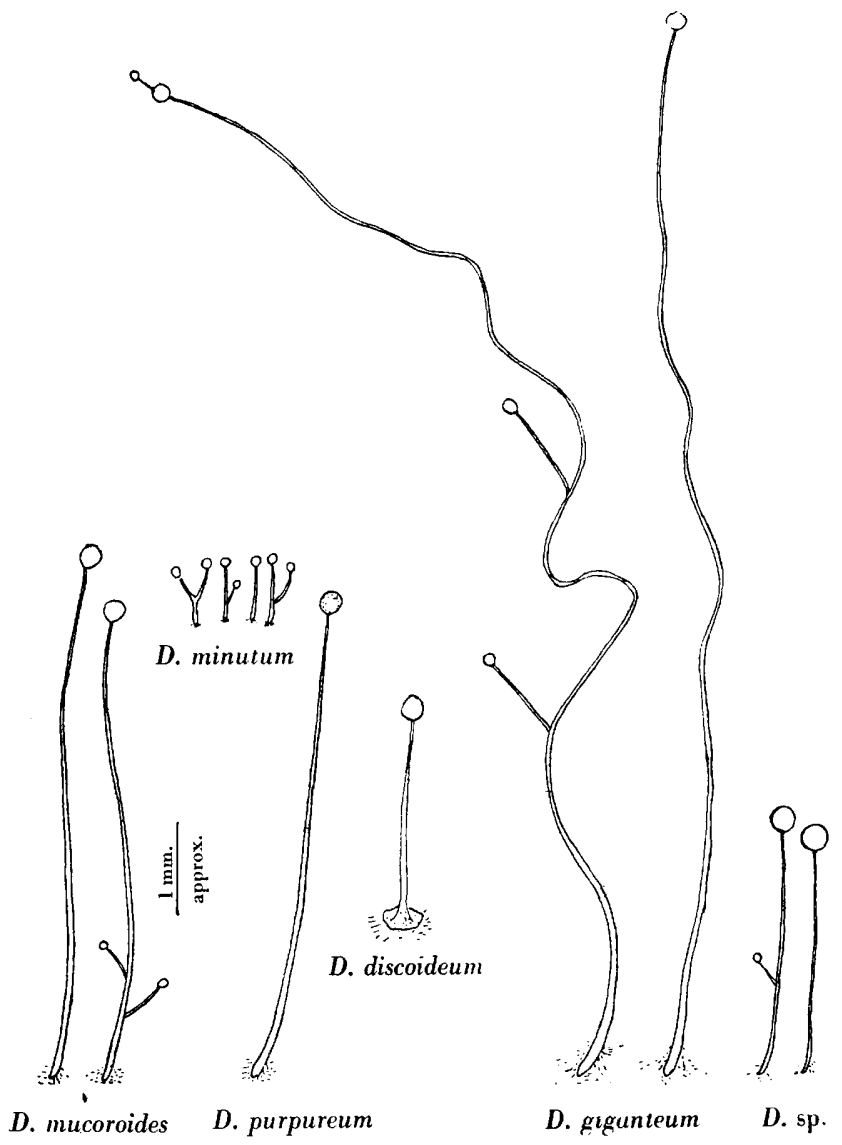

Text-fig. 1. Diagrammatic representation of the identifiable species of Dictyostelium. The figures are reproduced from Raper $(1940 a)$ excepting $D$. giganteum and Dictyostelium sp. D. mucoroides characterized by milky white sorus and long sorophore sometimes bearing one or more lateral branches; $D$. purpureum characterized by deep purple sori and unbranched sorophores; $D$. discoideum characterized by basal disk and erect tapering sorophores; $D$. minutum characterized by diminutive sorophores branched and unbranched; $D$. giganteum characterized by very long creeping sorophore sometimes bearing one or more lateral branches and small milky white sorus; Dictyostelium sp. characterized by short sorophore occasionally bearing one or two branches and with milky white sorus.

Dictyostelium giganteum sp.nov.

In agaro non nutriente cultum cum Bacterio coli, Pseudomonate fluorescente vel Aerobactro 1912 ad 21-23 ${ }^{\circ}$ : Myxamoebis varia magnitudine 10-18 $\times$ 7-12 $\mu$; sorocarpis repentibus, plerumque 17-25 mm. longis, interdum usque ad $30 \mathrm{~mm}$., saepe uno vel pluribus ramis lateralibus; sorophoris albis parte terminali flexuosis; soris rotundatis, interdum ovalibus, plerumque 150-300 $\mu$ in diam., maioribus et minoribus frequentibus, lacteo-albis; Sporis ellipticis, varia magnitudine 
5-10 $\times 2-3.5 \mu . \quad$ Ex cumulo putrescentis straminis ad fundum, Rothamsted, Harpenden, Herts. Sept. 1943.

"Cultivated upon non-nutrient agar with Bacterium coli, Pseudomonas fluorescens, or Aerobacter strain 1912 at 21-23 ${ }^{\circ}$ : Myxamoebae of variable size 10-18 $\times 7-12 \mu$; sorocarps creeping, usually $17-25 \mathrm{~mm}$. long, occasionally up to $30 \mathrm{~mm}$., frequently with one or more lateral branches; sorophores white, terminal region flexous; sori rounded, occasionally oval, commonly $150-300 \mu$ in diameter with larger and smaller specimens frequent, milk white; spores elliptical, size variable 5-10 $\times \mathbf{2 - 3 . 5} \mu$. Isolated from an actively decomposing compost heap of straw and sludge, Rothamsted farm, Harpenden, Herts, September, 1943.'

The detailed life cycle of this species has not yet been ascertained. The important stages in its life cycle are similar to those of D. mucoroides. $D$. giganteum is distinguished from other species by long creeping stalks and small sori (see Pl. 1, fig. 1, and Text-fig. 1). A type culture has been sent to the National Collection of Type Cultures, Lister Institute.

When a culture of $D$. giganteum is compared with $D$. mucoroides ( $\mathrm{Pl}$. 1, figs. 1,2 ) it is always found that, comparatively, very few sorocarps are produced by $D$. giganteum, most of the myxamoebae being sacrificed in the production of long creeping stalks. No migration of the pseudoplasmodium could be seen in $D$. giganteum such as was described by Raper (1935) for D. discoideum. Sometimes (as shown in Text-fig. 1) a small secondary sorocarp with generally a rounded sorus is seen attached to the sorus, although this type of arrangement is uncommon and cannot be produced at will.

D. giganteum has been isolated only twice, on both occasions from decomposing compost heaps. The production of very long creeping stalks may be of importance in the dispersal of the spores in such substrates. No marked differences from $D$. mucoroides in such characters as size of myxamoebae and spores could be observed.

On several occasions a species whose sorocarps are shorter than D. mucoroides has been isolated from soils (Text-fig. 1). It is not proposed to give it a name unless similar observations have been made by other workers under controlled cultural conditions and with a range of suitable bacterial associates. No detailed study of the life cycle of this species has yet been made. It resembles D. mucoroides in the general outlines of its life cycle and in the size of sori but it differs in the maximum dimensions of the sorocarps when grown under controlled conditions and with suitable bacterial associates on non-nutrient agar. Text-fig. 1 gives a diagrammatic representation of the species of the genus Dictyostelium which can easily be identified.

\section{Occurrence of Dictyostelium spp. in the soils of Great Britain}

To study the occurrence of Dictyostelium spp. in soils, samples were taken from the top $4 \mathrm{in}$. The method of isolation and culture was that already described. It seems that only two species, D. mucoroides and Dictyostelium sp., are commonly present in the soils of England, Wales and Scotland, though only a few samples have been so far examined from Scotland. Other easily 
identifiable species such as $D$. discoideum, D. minutum, D. purpureum, Polysphondylium violaceum and $\boldsymbol{P}$. pallidum have not been isolated from these soils. It seems strange that only two species of Dictyostelium have been found so far in British soils, and the same is true of the distribution of lytic myxobacteria (Singh, 1947).

Sixty-seven samples of arable and grassland soils from Hertfordshire, Berkshire, Bedfordshire, Wiltshire, Kent, Cornwall, Glamorganshire, Breconshire, Pembrokeshire and Aberdeen were examined. Dictyostelium spp. were found to be present in thirty-three of thirty-eight arable soils, and absent in five. Of twenty-nine grassland soils examined only three contained Dictyostelium spp. Two soil samples at a distance of $30 \mathrm{yd}$. from each other were collected on Harpenden Common. One soil had been under arable cultivation for 2 years and the other was permanent pasture; the cultivated soil gave plenty of fruiting bodies of $D$. mucoroides but none could be obtained from the soil under permanent grass. Miss F. J. Moore of the Plant Pathology Department, Rothamsted, found Dictyostelium fruiting bodies developing on potatoes infected with fungus when they were left in the laboratory for a few days.

No correlation between the $\mathrm{pH}$ of the soil and the distribution of Dictyostelium spp. was found in soils ranging from $\mathrm{pH} 4 \cdot 3$ to $7 \cdot 8$.

In addition to the soil samples mentioned above, the soils of all the classical plots of Barnfield and Broadbalk at Rothamsted were examined. Some of these soils have been treated with farmyard manure, some with artificial fertilizers only and some have been untreated. Dictyostelium spp. were found in all the plots. The presence of Dictyostelium species in these classical plots of Rothamsted where no fertilizer has been used, or only artificials have been added for 100 years or more, disproves the earlier belief that species of Dictyostelium are dung organisms. Their occurrence in dung merely indicates the presence of the bacterial food necessary for their development.

\section{Counts of Dictyostelium spp. in soil}

No satisfactory method of counting either the myxamoebae or the spores in soil has been developed. It is impossible to count myxamoebae directly because they are indistinguishable from the true small amoebae of the soil. The presence or absence of myxamoebae or of the spores at various dilutions can only be ascertained by the presence or absence of pseudoplasmodia and fruiting bodies. With the dilution method of counting holozoic Protozoa (Singh, 1946a,b) using Aerobacter strain 1912 as food on non-nutrient agar, the fruiting bodies of Dictyostelium spp. could be seen in cultures at several dilutions but their formation was so erratic that it was impossible to count the numbers either of myxamoebae or of spores.

\section{DISCUSSION}

The importance of Acrasieae in soil economy depends, first, on whether the myxamoebae can lead a trophic existence in soil and diminish the bacterial population, and, secondly, on their numbers. Some work has already shown that myxamoebae of two species of Dictyostelium migrate through sterilized 
soil and decrease the bacterial population rapidly. The formation of fruiting bodies takes place only at higher moisture contents (cf. Singh, 1946c). As both myxamoebae and the true amoebae which commonly occur in soil feed selectively on bacteria they may be important agents in bringing about qualitative changes in the bacterial flora of the soil.

This work was made possible by a grant from the Agricultural Research Council, to whom the author's thanks are due.

My best thanks are due to Dr H. G. Thornton, F.R.S., and Miss L. M. Crump for their interest in this work. Most of the strains of soil bacteria were kindly given to me by Miss L. M. Crump from her personal collection.

\section{REFERENCES}

BrefELD, O. (1869). Dictyostelium mucoroides. Ein neuer Organismus aus der Verwandschaft der Myxomyceten. Abh. Senckenb. naturf. Ges. 7, 85.

Brefeld, O. (1884). Polysphondylium violaceum und Dictyostelium mucoroides nebst Bemerkungen zur Systematik der Schleimpilze. Untersuch. Gesammt. Mykol. 6, 1.

Krzemieniewski, H. \& S. (1927). Z Mikroflory gleby w Polsce (Contribution à la microflore du sol en Pologne). Acta Soc. Bot. Polon. 4, 141.

Ourve, E. W. (1901). A preliminary enumeration of the Sorophorae. Proc. Amer. Acad. Arts Sci. 37, 333.

Raper, K. B. (1935). Dictyostelium discoideum, a new species of slime mold from decaying forest leaves. J. agric. Res. 50, 135.

RAPER, K. B. (1937). Growth and development of Dictyostelium discoideum with different bacterial associates. J. agric. Res. 55, 289.

RAPER, K. B. (1939). Influence of cultural conditions upon the growth and development of Dictyostelium discoideum. J. agric. Res. 58, 157.

RAPER, K. B. (1940a). The communal nature of the fruiting process in the Acrasieae. Amer. J. Bot. 27, 436.

RAPER, K. B. (1940 b). Pseudoplasmodium formation and organization in Dictyostelium discoideum. J. Elisha Mitchell sci. Soc. 56, 241.

RAPER, K. B. (1941). Dictyostelium minutum, a second new species of slime mold from decaying forest leaves. Mycologia, 33, 633.

Raper, K. B. \& Smith, N. R. (1939). The growth of Dictyostelium discoideum upon pathogenic bacteria. J. Bact. 38, 431.

Raper, K. B. \& Thom, C. (1932). The distribution of Dictyostelium and other slime molds in soil. J. Wash. Acad. Sci. 28, 93.

RAPer, K. B. \& Thom, C. (1941). Interspecific mixtures in the Dictyosteliaceae. Amer. J. Bot. 28, 69.

Singh, B. N. (1941). Selectivity in bacterial food by soil amoebae in pure mixed culture and in sterilized soil. Ann. appl. Biol. 28, 52.

Singh, B. N. (1942). Selectivity in bacterial food by soil flagellates and amoebae. Ann. appl. Biol. 29, 18.

Singh, B. N. (1945). The selection of bacterial food by soil amoebae, and the toxic effects of bacterial pigments and other products on soil Protozoa. Brit. J. exp. Path. 26, 316.

Singh, B. N. (1946 $a)$. A method of estimating the number of soil Protozoa, especially amoebae, based on differential feeding of bacteria by Protozoa. Ann. appl. Biol. $33,112$.

Singh, B. N. (1946 $b)$. Silica jelly as a substrate for counting holozoic Protozoa. Nature, Lond., 157, 302. 
Journal of General Microbiology, Vol. 1, No. 1

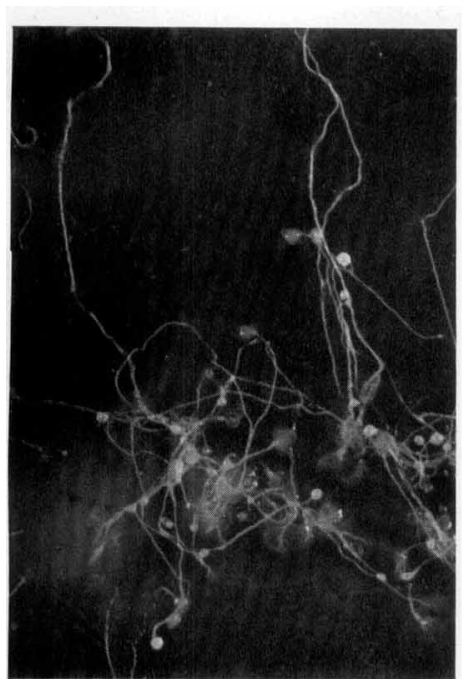

Fig. 1

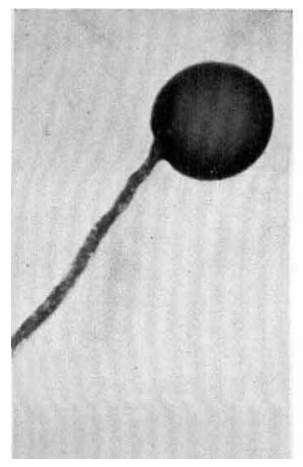

Fig. 4

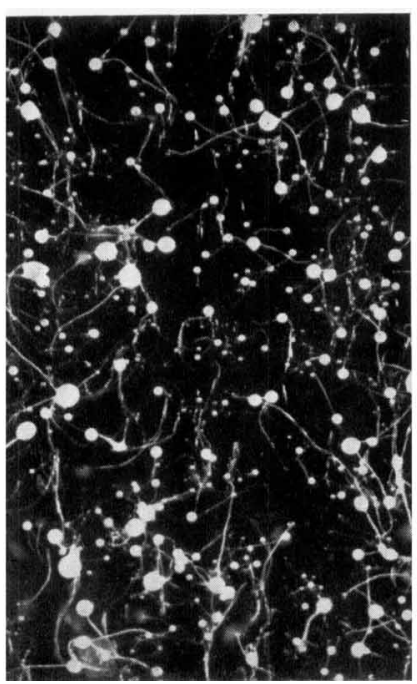

Fig. 2

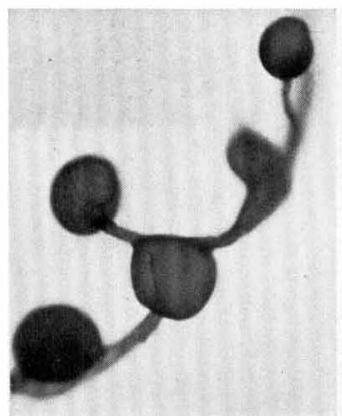

Fig. $\overline{5}$

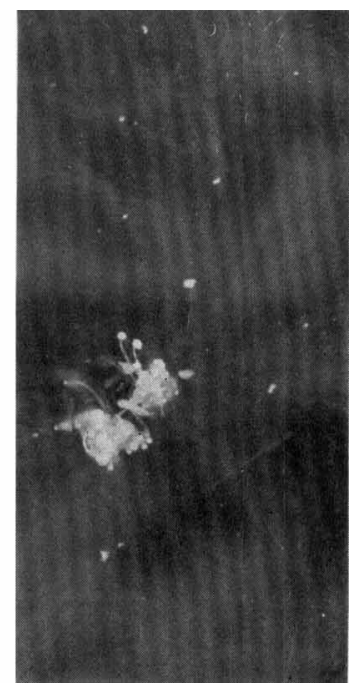

Fig. 3

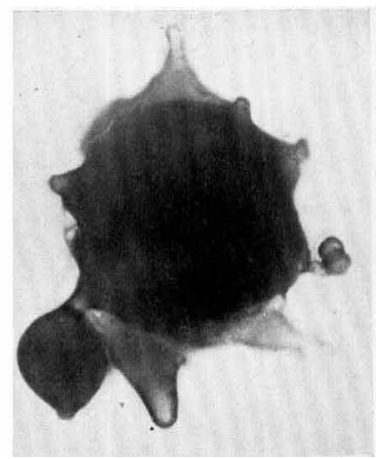

Fig. 6

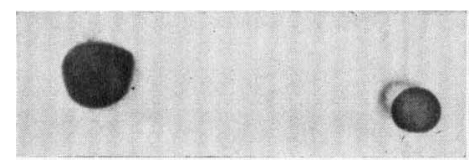

Fig. 7

13. N. Singh-S'Tudies on SOIL ACRASILAJ. Plat'le 1 
SiNGH, B. N. $(1946 c)$. Soil Acrasieae and their bacterial food supply. Nature, Lond., $157,133$.

Singh, B. N. (1947). Myxobacteria in soils and composts; their distribution, number and lytic action on bacteria. J. gen. Microbiol. $1,1$.

\section{EXPLANATION OF PLATE}

Fig. 1. Dictyostelium giganteum sp.nov., grown on non-nutrient agar and with Aerobacter sp. (strain 1912) as food supply. Only a part of the sorophores can be seen in the photograph.

Fig. 2. Dictyostelium mucoroides grown under similar conditions and with the same bacterial food supply as $D$. giganteum.

Fig. 3. Abnormal growth of $D$. mucoroides grown on non-nutrient agar with a yellow strain (6699) of soil bacteria as food supply. There is incomplete clearing of the bacterial patch and the sorophores are deformed and clumped in the centre. The fruiting bodies produced in other places have no stalks.

Figs. 1-3 are of the same magnification. $(\times 6$.

Fig. 4. Showing a normal fruiting body of $D$. mucoroides grown on non-nutrient agar and with Aerobacter sp. as food supply.

Fig. 5. Showing abnormal fruiting bodies of $D$. mucoroides grown on non-nutrient agar with a red bacterium (strain 0312) as food supply.

Figs. 6, 7. Showing abnormal fruiting bodies of $D$. mucoroides grown on non-nutrient agar with a yellow bacterium (strain 6699) as food supply.

Figs. $4-7$ are of the same magnification. $(\times 50$.

(Received 26 March 1946) 